\title{
INFLUENCE OF BREASTFEEDING GIVING TOPICAL TO OLD RELEASE OF UMBILICAL CORD AT MIDWIFE INDEPENDENT PRACTICE ANATAPURA AND SETIA IN PALU
}

\author{
Dwi Yani Ratna Dewi ${ }^{1}$, Muliani ${ }^{2 K}$, Henrietta Imelda Tondong ${ }^{3}$ \\ ${ }^{1 ’ 2}{ }^{\prime 3}$ Prodi D.IV Kebidanan Jurusan Kebidanan Poltekkes Kemenkes Palu \\ Email Penulis Korespondensi ${ }^{(\mathrm{K})}$ : murid_lewa@yahoo.co.id
}

\begin{abstract}
The background of cord care is to keep the umbilical cord clean, dry and help protect newborns from possible infections. The umbilical cord fades faster and reduces the risk of infection. The content of breast milk, namely leukocyte cells, proteolytic enzymes, and immunological substances that can help accelerate the release of the umbilical cord. The study aimed to determine the effect of topical breastfeeding on the length of umbilical cord release in newborns at BPM Anatapura and Setia Palu BPM. The method used was pre-experiment with Static Group Comparison. The study population was all newborns aged 0 days until the cord was released, born at BPM Anatapura and BPM Setia Palu. The sample was divided into 2 groups (intervention and control), the number of samples was 15 for each group, so that a total of 30 samples were taken by consecutive sampling technique. Data analysis used was univariate and bivariate with Independent t-test. The results showed that the mean cord release in the topical breastfeeding group $(102.7+22.08$ hours) was smaller than the open dry treatment group (145, $36+37.63$ hours) in the $95 \%$ CI with $\rho$-value of 0.001 . The topical ASI group had a chance of 1.42 times (42.66 hours) experiencing umbilical cord release more quickly than the open dry treatment group. The conclusion of the study was the effect of topical breastfeeding on the length of umbilical cord release. The results of the study can be used as reference references in providing health services, especially simple umbilical cord care using topical breast milk.
\end{abstract}

Keywords: Topical Breastfeeding, old release of the umbilical cord

\section{PENDAHULUAN}

\section{Latar Belakang}

Perawatan tali pusat, yaitu menjaga tali pusat tetap bersih dan kering serta membantu melindungi bayi baru lahir dari kemungkinan infeksi ${ }^{(1)}$. Daerah tali pusat berpotensi menjadi media pertumbuhan beberapa mikroorganisme berbahaya atau yang bermanfaat (commensals), sedangkan yang berbahaya (misalnya, Clostridium tetani) ${ }^{(2)}$. Lama pelepasan tali pusat dikatakan cepat jika $<5$ hari, normal jika antara 5-7 hari, dan lambat jika $>7$ hari $^{(3)}$. Umumnya, umbilicus atau tali pusat lepas saat satu minggu setelah bayi lahir dan luka sembuh dalam 15 hari $^{(4)}$.

Cara terbaik untuk mengobati tali pusat setelah lahir merupakan suatu isu yang kontroversial, terutama di negara-negara berkembang yang memiiki kepercayaan lokal. Upaya untuk mengidentifikasi dan menerapkan intervensi perawatan tali pusat yang terjangkau, efektif, dan berbasis masyarakat masih dilakukan sehingga dapat mengurangi infeksi terkait kematian neonatal di negara-negara berkembang ${ }^{(2)}$.

Air Susu Ibu (ASI) terdapat sel leukosit, enzim proteolitik, dan zat immunologi yang membantu mempercepat pelepasan tali pusat. Tali pusat yang semakin cepat lepas akan mengurangi risiko terjadinya infeksi, dengan memperhatikan kebersihan sekitar tali pusat dan cuci tangan sebelum dan sesudah merawat tali pusat ${ }^{(5)}$. Lepasnya tali pusat dipengaruhi oleh 
beberapa hal diantaranya timbulnya infeksi pada tali pusat, apabila terjadi infeksi pada tali pusat maka akan semakin lama puput ${ }^{(3)}$.

Infeksi merupakan salah satu penyebab utama kematian bayi minggu pertama yang diantaranya dapat terjadi karena perawatan tali pusat yang tidak tepat ${ }^{(6)}$. Bayi hingga usia kurang satu bulan merupakan golongan umur yang memiliki risiko gangguan kesehatan paling tinggi, berbagai masalah kesehatan dapat muncul ${ }^{(7)}$.

Tetanus neonatorum adalah penyakit yang terjadi pada neonatus (bayi berusia 1 bulan) yang disebabkan oleh clostrodium tetani, yaitu kuman yang mengeluarkan toksin (racun) dan menyerang sistem saraf pusat. Spora kuman tersebut masuk ke dalam tubuh bayi melalui pintu masuk satu-satunya, yaitu tali pusat yang dapat terjadi baik saat pemotongan tali pusat ketika bayi baru lahir maupun saat perawatannya sebelum puput (terlepasnya tali pusat $)^{(8)}$.

World Health Organization (WHO) melaporkan bahwa tahun 2015 terdapat 973.000 neonatal yang menderita tetanus neonatorum di Asia Tenggara, sedangkan di Indonesia terdapat 53 neonatal dan 27 neonatal meninggal karena tetanus neonatorum ${ }^{(9)}$.

Menurut WHO, setiap tahun terdapat 3,3 juta kematian neonatal di dunia. Tahun 2015 Angka Kematian Neonatal (AKN) di dunia berjumlah 19.2 per 1000 kelahiran hidup, di Asia Tenggara berjumlah 24.3 per 1.000 kelahiran hidup, sedangkan di Indonesia berjumlah 13.5 per 1.000 kelahiran hidup atau 74.000 kematian neonatal. Indonesia merupakan salah satu negara dengan Angka Kematian Neonatal (AKN) tertinggi, yaitu berada pada posisi ke enam di Asia Tenggara ${ }^{(10)}$.

Tingginya angka kematian bayi di Indonesia disebabkan oleh berbagai faktor, diantaranya adalah faktor penyakit infeksi dan kekurangan gizi. Beberapa penyakit yang masih menjadi kematian terbesar dari bayi, diantaranya penyakit diare, tetanus, gangguan perinatal, dan radang saluran pernapasan bagian bawah ${ }^{(11)}$.

Berdasarkan data Dinas Kesehatan Provinsi Sulawesi Tengah, tahun 2015 Banggai Kepulauan merupakan kabupaten yang memiliki Angka Kematian Neonatal (AKN) tertinggi 26,88 per 1000 kelahiran hidup dari jumlah lahir hidup 1.823 dan jumlah kematian 49, sedangkan Kota Palu berada di posisi terakhir dengan AKN 2,08 per 1000 kelahiran hidup dari jumlah lahir hidup 6.739 serta jumlah kematian $14^{(12)}$.

Kematian neonatal disebabkan oleh Bayi Berat Lahir Rendah (BBLR) 29,30\%, Asfiksia 27,42\%, Kelainan Bawaan 5,38\%, Sepsis 2,69\%, Tetanus Neonatorum 0,81\%, dan lain-lain $34,41 \%$. Terdapat 3 kasus tetanus neonatorum dan 9 kasus sepsis ${ }^{(12)}$.

Hasil penelitian yang dilakukan di Kenya (Universitas Nairobi), menyatakan bahwa pembersihan tali pusat menggunakan 4\% Chlorhexidine dapat mengurangi risiko kematian neonatal dan sepsis (omphalitis) ${ }^{(13)}$. Penggunaan Chlorhexidine dapat mengurangi risiko kematian neonatal hingga 23\%, akan tetapi dapat menunda pelepasan tali pusat sekitar 1-7 hari $^{(14)}$. Demikian pula hasil penelitian di Nepal tentang dampak penggunaan $4 \%$ Chlorhexidine yang merupakan antiseptik membandingkan dengan penggunaan Air Susu Ibu (ASI) pada perawatan tali pusat. Hasil studi menunjukkan bahwa rata-rata lama waktu pelepasan tali pusat kelompok Air Susu Ibu (ASI) (7.15 \pm 2.15 hari) lebih pendek daripada kelompok Chlorhexidine $(13,28 \pm 6,79 \text { hari })^{(15)}$.

Hasil penelitian yang membandingkan penggunaan ASI dan ethanol terhadap lama pelepasan tali pusat menunjukkan bahwa, pelepasan tali pusat menggunakan ASI lebih cepat (4.3 hari) dibandingkan ethanol (8.8 hari) ${ }^{(16)}$. Demikian pula penelitian yang membandingkan waktu pelepasan tali pusat menggunakan topikal ASI dan perawatan kering terbuka menunjukkan bahwa perbedaan rerata waktu lepas tali pusat dengan topikal ASI lebih singkat (5.69 hari) dibandingkan dengan perawatan kering terbuka (7.06 hari). Model asuhan perawatan topikal ASI pada tali pusat bayi dapat mencegah omphalitis, menunjukkan bahwa 
masih terdapat 1 dari 15 bayi yang mengalami omphalitis, namun terdapat 4 dari 15 bayi yang mengalami omphalitis ${ }^{(5)}$.

Berdasarkan data Dinas Kesehatan Kota Palu tahun 2015, Puskesmas Kamonji merupakan salah satu pusat pelayanan kesehatan yang memiliki jumlah persalinan terbanyak 1.051 dengan kelahiran bayi hidup $1.049^{(12)}$. Persalinan terbanyak yang berada di wilayah kerja Puskesmas Kamonji terdapat pada Bidan Praktik Mandiri (BPM) ${ }^{(17)}$.

Bidan Praktik Mandiri (BPM) adalah sebuah institusi pelayanan kesehatan secara mandiri yang memberikan asuhan dalam lingkup praktik kebidanan ${ }^{(18)}$. Jumlah persalinan di Bidan Praktik Mandiri (BPM) Anatapura sebanyak 167 dan di BPM Setia sebanyak 290 persalinan $^{(19),(20)}$.

\section{Tujuan}

Tujuan penelitian ini adalah diketahui pengaruh pemberian topikal ASI terhadap ratarata lama pelepasan tali pusat di BPM Anatapura dan BPM Setia.

\section{METODE PENELITIAN}

Penelitian ini bersifat Pra-eksperimen dengan rancangan perbandingan kelompok statis (Static Group Comparison). Peneliti memberikan perlakuan atau intervensi pada kelompok eksperimen (X) dan akan diobservasi (02). Hasil observasi ini kemudian dikontrol atau dibandingkan dengan hasil observasi pada kelompok kontrol yang tidak menerima intervensi. Penelitian ini dilaksanakan pada bulan 22 Mei- 30 Juli 2017. Populasi dalam penelitian ini adalah semua bayi baru lahir dengan umur 0 hari hingga tali pusat pupus yang lahir di BPM Anatapura dan BPM Setia Palu Propinsi Sulawesi Tengah, dengan jumlah sampel masing-masing kelompok intervensi dan kontrol adalah 15 bayi dengan teknik pemilihan sampel secara consecutive sampling. Adapun kriteria inklusi sampel adalah bayi lahir cukup bulan (38-42 minggu, berat badan lahir bayi normal (2500-4000 gram) maupun berat badan dalam kondisi Kecil Masa Kehamilan (KMK), produksi ASI ibu bayi cukup. Teknik pengumpulan data yaitu peneliti menyiapkan ASI perah sebanyak 2-3 ml dari ibu kandung bayi baru lahir yang disimpan pada wadah yang bersih. Setelah 8 jam bayi lahir, bersihkan bayi menggunakan air bersih dan lap menggunakan kain bersih, ambil kassa dan celupkan di dalam wadah yang telah berisi ASI hingga seluruh permukaan kassa terbasahi oleh ASI. Oleskan kassa yang telah diberikan ASI pada puntung tali pusat mulai pada pangkal sampai ke ujung dan dibiarkan kering terbuka.

\section{HASIL DAN PEMBAHASAN}

Penelitian dilaksanakan pada kelompok intervensi sejumlah 15 sampel yang diberikan topikal ASI dan kelompok kontrol dibiarkan dengan perawatan kering terbuka. Pada kelompok intervensi ASI dioleskan pada puntung tali pusat mulai pada pangkal sampai ke ujung menggunakan kassa yang seluruh permukaannya telah dibasahi dengan ASI dan dibiarkan kering terbuka sejak umur 0 hari 8 jam setelah bayi lahir. Pengukuran waktu lepasnya tali pusat dimulai saat bayi baru lahir hingga lepasnya tali pusat. Ibu yang belum memiliki pengeluaran ASI dalam 24 jam pertama dieksklusikan dalam penelitian ini.

Jumlah sampel dalam penelitian ini ditentukan oleh peneliti sebelum dilakukan penelitian. Peneliti berusaha mengontrol variansi data responden untuk penentuan sampel berdasarkan paritas, jenis kelamin, dan berat badan, yaitu responden pada kelompok intervensi harus memiliki paritas yang sama dengan responden pada kelompok kontrol, begitupun sebaliknya. Pemberian intervensi dilakukan 8 jam setelah bayi lahir. 
Selanjutnya memberikan edukasi sebagai salah satu pelayanan yang diberikan kepada ibu pasca persalinan tentang perawatan tali pusat, sehingga perawatan yang dilakukan oleh kedua klinik bersalin (BPM) adalah sesuai Standar Operasional Prosedur (SOP), yaitu tidak membubuhi apapun pada tali pusat (perawatan kering terbuka).

Berdasarkan hasil pengolahan data, maka dapat disajikan hasil analisis data yang telah dilakukan, yaitu dengan menyajikan karakteristik responden seperti pada tabel berikut ini:

Tabel 1

Distribusi Responden berdasarkan, Paritas, dan Berat Badan pada Kelompok Intervensi dan Kelompok Kontrol di BPM Anatapura dan BPM Setia, 2017

\begin{tabular}{llcccc}
\hline \multirow{2}{*}{ Karakteristik responden } & \multicolumn{2}{c}{ Kelompok } \\
& & \multicolumn{2}{c}{ Intervensi } & \multicolumn{2}{c}{ Kontrol } \\
& & $\mathrm{f}(15)$ & $\%$ & $\mathrm{f}(15)$ & $\%$ \\
\hline \multirow{3}{*}{ Paritas } & Primipara & 2 & 13 & 3 & 20 \\
& Multipara & 13 & 87 & 10 & 67 \\
& Grandemultipara & 0 & 0 & 2 & 13 \\
\hline \multirow{2}{*}{ Jenis Kelamin } & Laki-Laki & 7 & 47 & 7 & 53 \\
& Perempuan & 8 & 53 & 8 & 53 \\
\hline \multirow{3}{*}{ Berat Badan } & $2500-3000$ & 6 & 40 & 8 & 47 \\
& $\leq 3500$ & 8 & 53 & 7 & 47 \\
& $\leq 4000$ & 1 & 7 & 0 & 0 \\
\hline
\end{tabular}

Berdasarkan uraian pada tabel 1 menunjukkan bahwa pada kelompok intervensi, paritas terbanyak adalah multipara sejumlah 13 orang $(87 \%)$, jenis kelamin terbanyak yaitu perempuan sejumlah $8(53 \%)$, dan berat badan terbanyak $\leq 3500$ sejumlah $8(53 \%)$, sedangkan pada kelompok kontrol jumlah paritas terbanyak juga multipara sejumlah 10 orang $(67 \%)$, jenis kelamin terbanyak yaitu perempuan sejumlah $8(53 \%)$, dan berat badan terbanyak 2500-3000 sejumlah $8(53 \%)$.

\section{Perbedaan Lama Pelepasan Tali Pusat pada kelompok topikal ASI dan Perawatan kering Terbuka}

Hasil analisis waktu perbedaan pelepasan tali pusat pada setiap kelompok penelitian dapat dilihat pada tabel, berikut ini:

Tabel 2

Analisis Perbedaan Lama Pelepasan Tali Pusat pada Kelompok Intervensi dan Kontrol di BPM Anatapura dan BPM Setia Tahun 2017

\begin{tabular}{|c|c|c|c|c|}
\hline \multirow{2}{*}{ Perawatan Tali Pusat } & \multirow{2}{*}{$\mathrm{n}$} & Median & \multirow{2}{*}{ Rerata \pm s.b } & \multirow[b]{2}{*}{$\rho$} \\
\hline & & (Minimum-maksimum) & & \\
\hline Lama Pelepasan Tali Pusat & \multirow{2}{*}{15} & \multirow{2}{*}{$105,45(58,05-147,05)$} & \multirow{2}{*}{$102,7 \pm 22,08$} & \multirow{4}{*}{0,001} \\
\hline Topikal ASI & & & & \\
\hline Lama Pelepasan Tali Pusat & \multirow{2}{*}{15} & \multirow{2}{*}{$153,58(72,50-192,30)$} & \multirow{2}{*}{$145,36 \pm 37,63$} & \\
\hline Perawatan Kering Terbuka & & & & \\
\hline
\end{tabular}

24 | Penerbit: Jurusan Kebidanan, Poltekkes Kemenkes Palu 
Berdasarkan tabel 2 dapat dilihat bahwa kedua kelompok memiliki jumlah responden yang sama, yaitu 15 orang. Nilai tengah (median) pada kelompok topikal ASI lebih kecil $(105,45)$ daripada kelompok perawatan kering terbuka $(153,58)$ dengan waktu pelepasan tali pusat tercepat pada kelompok topikal ASI adalah selama 58,05 jam dan paling lama 147,05 jam. Nilai mean (rerata) dan simpangan baku pada kelompok topikal ASI juga lebih kecil daripada kelompok perawatan kering terbuka, yaitu 102,7 jam dan 22,08 jam.

Nilai $\rho$-value adalah 0,001 menunjukkan bahwa ada pengaruh topikal ASI terhadap lama pelepasan tali pusat. Jika dilihat secara keseluruhan, maka hasil menunjukkan bahwa waktu pelepasan tali pusat pada kelompok topikal ASI lebih cepat daripada kelompok perawatan kering terbuka. Bayi baru lahir yang mendapatkan topikal ASI berpeluang 1,42 kali mengalami pelepasan tali pusat lebih cepat dibandingkan bayi baru lahir intervensi perawatan kering terbuka.

\section{PEMBAHASAN}

Apabila ditinjau dari karakteristik responden, yaitu pada variabel paritas jumlah terbanyak antara ke dua kelompok terdapat pada multipara, pada variabel jenis kelamin dapat dilihat bahwa responden berjumlah sama pada ke dua kelompok, sedangkan variabel berat badan jumlah terbanyak antara ke dua kelompok terdapat pada $\leq 3500$ sehingga dapat disimpulkan bahwa ke dua kelompok memilki variansi data yang hampir sama dalam paritas, jenis kelamin, dan berat badan.

Berdasarkan hasil analisis deskriptif, waktu pelepasan tali pusat tercepat pada kelompok intervensi adalah 58,05 jam dan terlama 147,05 jam dengan median 105, 45 dan rerata 102,7, sedangkan pada kelompok kontrol waktu tercepat adalah 72,50 jam dan terlama 192,30 jam dengan median 153, 58 dan rerata 145, 36 jam. Jika dibandingkan rerata lama pelepasan tali pusat, maka dapat dilihat bahwa pada kelompok intervensi 1,42 kali $(42,66$ jam) mengalami pelepasan tali pusat lebih cepat dibandingkan dengan kelompok kontrol.

Sebelum melakukan uji statistik terlebih dahulu dilakukan uji normalitas untuk melihat distribusi data penelitian. Uji normalitas yang digunakan adalah uji Shapiro-Wilk dan didapatkan nilai $\rho$ sebesar 0,94 pada kelompok intervensi dan 0,204 pada kelompok kontrol sehingga dapat disimpulkan bahwa distribusi data normal. Setelah diketahui bahwa data terdistribusi normal, maka peneliti menggunakan uji parametrik yaitu independent $t$ - test sebagai uji statistik. Berdasarkan hasil independent t- test pada tingkat kepercayaan 95\% diperoleh nilai $\rho$ adalah sebesar 0,001 atau $<0,05$ sehingga dapat disimpulkan bahwa terdapat pengaruh topikal ASI terhadap lama pelepasan tali pusat, yaitu bayi baru lahir yang berikan intervensi topikal ASI berpeluang 1.42 kali lebih cepat pelepasan tali pusatnya daripada bayi baru lahir yang tidak diberikan intervensi apapun (perawatan kering terbuka).

Hasil ini sejalan dengan penelitian yang dilakukan di Iran dengan membandingkan dampak penggunaan ASI dan perawatan kering terbuka pada perawatan tali pusat. Hasil studi menunjukkan bahwa rata-rata lama waktu pelepasan tali pusat kelompok ASI (6.5 \pm 1.93 hari) lebih pendek daripada kelompok perawatan kering terbuka $(7.54 \pm 2.37 \text { hari })^{(21)}$. Hasil penelitian ini sesuai dengan teori yang dikemukakan bahwa ASI terdapat sel leukosit, enzim proteolitik, dan zat immunologi yang membantu mempercepat pelepasan tali pusat ${ }^{(22)}$.

Hasil ini sesuai dengan penelitian sebelumnya yang dilakukan oleh Kasiati, dkk (2013) membandingkan topikal ASI dan perawatan kering terbuka pada perawatan tali pusat menunjukkan bahwa rerata waktu pelepasan tali pusat menggunakan topikal ASI 5.6 hari dengan waktu terpendek 94 jam (4.1 hari) dan terpanjang 199 jam (8.7 hari), sedangkan pada perawatan kering terbuka didapatkan rerata waktu pelepasan tali pusat 6.9 hari dengan waktu terpendek 105 jam (4.05 hari) dan terpanjang 241 jam (10,1 hari). 
Hasil penelitian ini menunjukkan bahwa terdapat beberapa bayi pada kelompok intervensi yang waktu pelepasan tali pusat di atas rerata, hal ini disebabkan oleh kelembaban tali pusat pada bayi yang menggunakan diapers sehingga kurang mendapatkan paparan udara dan mempengaruhi proses pengeringan dan pelepasan tali pusat. Selain itu, lingkungan dapat mempengaruhi proses pengeringan dan pelepasan tali pusat karena proses pelepasan tali pusat merupakan proses yang kompleks, tali pusat akan mengering dan menghitam yang dibantu oleh mikroorganisme sehingga lingkungan dan perawatan harus bersih.

Infeksi dapat mempengaruhi waktu pelepasan tali pusat karena sesuai hasil penelitian yang dilakukan di Nepal bahwa ASI efektif sebagai khlorheksidin (antibiotik spektrum luas) dalam mengurangi tanda-tanda infeksi ${ }^{(15)}$. Sesuai dengan teori yang dikemukakan bahwa pada Air Susu Ibu terkandung sel-sel darah putih yang dapat melindungi bayi dari infeksi ${ }^{(23)}$.

Penelitian lain menunjukkan bahwa puntung tali pusat yang diberikan perawatan topikal ASI dapat mengurangi bakteri mikroorganisme patogen termasuk S. Aureus, E. Coli, dan basil gram negatif sehingga dapat mempercepat pelepasan tali pusat ${ }^{(21)}$.

Sesuai dengan penelitian ini bahwa penggunaan topikal ASI pada perawatan tali pusat merupakan tindakan yang sederhana, mudah, murah, dan efektif karena kandungan ASI sebagai anti inflamasi dan mencegah infeksi sehingga dapat mempercepat pelepasan tali pusat, namun kebersihan dalam perawatan tali pusat harus diperhatikan karena dapat memengaruhi lama pelepasan tali pusat.

\section{SIMPULAN DAN SARAN}

Berdasarkan hasil penelitian, dapat disimpulkan bahwa ada pengaruh pemberian topikal Air Susu Ibu (ASI) terhadap lama pelepasan tali pusat, yaitu bayi baru lahir yang mendapatkan topikal ASI berpeluang 1,42 kali (42,66 jam) mengalami pelepasan tali pusat lebih cepat dibandingkan bayi baru lahir yang tidak diberikan intervensi apapun dengan perawatan kering terbuka. Hasil penelitian ini dapat diterapkan diberbagai klinik dan dijadikan sumber rujukan pada perawatan tali pusat secara sederhana, mudah, murah, efektif dengan menggunakan topikal Air Susu Ibu (ASI).

\section{UCAPAK TERIMA KASIH}

Ucapan terima kasih disampaikan kepada Bidan Sriwati, SST owner BPM Anatapura dan Bidan Hj.Marsetia, SST owner BPM Setia, dan teman-teman yang ikut membantu dalam penelitian ini.

\section{DAFTAR PUSTAKA}

1. Wahyuni, S. 2012. Asuhan Neonatus, Bayi, \& Balita. EGC. Jakarta.

2. A.N. Megrin, A.A, \& Talat, M.A. Pengaruh Aplikasi topikal dari Susu Ibu pada Pemisahan Tali Pusat untuk Newborn Bayi. Vol.4. ISSN= 2328-5753. Hal: 288-296. (http://www.sciencepublishinggroup.com).

3. Sodikin. 2009. Buku Saku Perawatan Tali Pusat. EGC. Jakarta.

4. Hastuti. 2013. Pengetahuan Ibu tentang Perawatan Tali Pusat Berhubungan dengan Waktu Lepas Tali Pusat. Vol. 10. Hal: 193-198. (https://ejournal.say.ac.id).

5. Sari, F. Nurdianti, S. \& Astuti, A. 2016. Perbandingan Penggunaan Topikal ASI dengan Perawatan Kering terhadap Lama Pelepasan Tali Pusat Bayi. Jurnal Kebidanan dan Keperawatan. Vol. 12. No. 2. Hal: 90-94. Akademi Kebidanan Mitra Husada Medan. (https://analis.say.ac.id.).

26 | Penerbit: Jurusan Kebidanan, Poltekkes Kemenkes Palu 
6. Maryunani, A. \& Nurhayati. 2008. Buku Saku Asuhan bayi Baru Lahir Normal. EGC. Jakarta.

7. Departemen Kesehatan Republik Indonesia. Survei Demografi dan Kesehatan Indonesia. 2015. Kesehatan Anak. Indonesia.

8. Rukiyah, A.Y. \& Yulianti, L. 2014. Asuhan Neonatus, Bayi, dan Anak Balita. TIM. Jakarta.

9. World Health Organization. 2015 a Maternal and neonatus tetanus Eliminate. (http://cdrwww.who.int).

10. World Health Organization. 2015 . Neonatal Mortality Rate. (http://apps. who.int).

11. Dwienda, O. Maita, L. Saputri, M. \& Yulviana, R. 2014. Bahan Ajar Asuhan Kebidanan Neonatus Bayi/Balita dan Anak Prasekolah untuk Para Bidan. Deepublish. Yogyakarta.

12. Dinas Kesehatan Provinsi Sulawesi Tengah. Angka Kematian Neonatal Tahun 2015. Bagian Kesehatan Ibu dan Anak Provinsi Sulawesi Tengah. Palu.

13. Karumbi, J. Mulaku, M. Aluvaala, J. English, M. \& Opiyo, M. 2013. Topical Umbilical Cord Care for Prevention of Infection and Neonatal Mortality. Vol. 32. Hal: 78-83. (https://www.ncbi.nlm).

14. Imdad, A. Mullani, L, C. Baqui, A, H. Arifeen, S, E. Tielsch, J, M. Khatry, S, K. dkk 2013. The Efect of Umbilical Cord Cleansing with Chlorhexidine on Omphalitis and Neonatal Mortality in Community Settings in Developing Countries: a Meta-Analysis. Vol. 13. Suppl. 3. (https://bmcpublichealth.biomedicentral.com).

15. Abbaszadeh, F. Hajizadeh, Z. \& Jahangiri, M. 2015. Comparing the Impact of Topical Application Human Milk and Chlorhexidine on Cord Separation Time in Newborns. Vol. 32. Hal: 239-243. (www.ncbi.nlm).

16. Yulanda, A.N., Andikawati. \& Sya'id, A. Effectiveness of Applying Breastfeeding /Milk on Umbilical Cord Removal Compared to Ethanol and Dry Cord Care. (eprints.ners.unair.ac.id).

17. Puskesmas Kamonji. 2015. Data Persalinan \& Bayi Baru Lahir. Palu.

18. Syafrudin. \& Hamidah. 2009. Kebidanan Komunitas. EGC. Jakarta.

19. Bidan Praktik Mandiri Anatapura. 2016. Data Persalinan Normal. Palu.

20. Bidan Praktik Mandiri Setia. 2016. Data Persalinan Normal. Palu.

21. Golsham, M. \& Hossein, M. 2013. Impact of Etanol, Dry Cord Care, and Human Milk on the Time For Umbilical Cord Separation. Vol. 63. No. 9.

22. Quattrin, R. Labocci, K. Tina, A, L, D. Gallina, L. Pittini, C. \& Brusaferro, S. \& 70\% Alcohol Versus Dry Cord Care in the Umbilical Cord Care. Vol. 95. No. 14. (www.ncbi.nlm.nih.gov/pmc/articles/PMC4998765).

23. Ari, D.R.K. \& Adriani, F.R. 2015. Membesarkan Anak Hebat dengan ASI. Citra Media Pustaka. Yogyakarta. 